\title{
Reflection of the Czech President T.G. Masaryk on Russia and the Russian Revolution
}

\author{
Natalia Bondarenko \\ Metadisciplinary Training and Convergent Programs Centre \\ Moscow Institute of Open Education \\ Moscow, Russia
}

\begin{abstract}
The 'Russian issue' was one of the overriding for President of Czechoslovakia Tomas G. Masaryk. He was well acquainted with works of F.M. Dostoyevsky, I. V. Kireevsky, met with L.N. Tolstoy and V.I. Lamansky. He had initiated Czechoslovakia's substantial aid to the first-generation Russian immigrants in his republic and viewed the developments in October 1917 as disastrous for Russia. The series of his articles "Our problems and the Soviet Russia", written during the $1920 \mathrm{~s}$, cautions Czechs against illusions of the Soviet Russia's experience and against following the example of Marxism established in Russia.
\end{abstract}

Keywords-President of Czechoslovakia Tomas Masaryk; Russian revolution in 1917; Bolsheviks; Russian Action in the Czech Republic

\section{INTRODUCTION}

Different representatives of the Eastern Europe were treating the tragic events in 1917 following no particular pattern - in the era of developed socialism the October revolution was regarded as the working class' victory over capitalism, while in perestroika the liberal press' appraisal of the historical developments very sceptically.

On the threshold of the centenary of Russian revolutions in 1917, their analysis by representatives of the Slavonic scientific and political elite arouse special interest, including that of Tomas Masaryk, the first President of the Czech Republic (1850-1937). His anti-bolshevist assessment of the negative implications caused by the October revolution in 1917 explains why Masaryk's philosophical works were scarcely published in Russia and only a limited number of researchers is familiar with them.

Among such competent publications dedicated to the personality and scientific works of the Czech President there are "T.G. Masaryk, Philosophy-Sociology-Politics. Selectas" (2003), "T.G. Masaryk and 'Russian Action' of the Czech government: on 150 years of the birth of T.G. Masaryk" (2005); Yu. R. Kansky, M.V. Lomonosova, O.M. Malevich, I.M. Porochkina, D. Ya. Travnin "T.G. Masaryk. On the occasion of the 160-years anniversary" (2010). Chapters of "Czechia and Slovakia in the 20th century. Outlines of history, Book 1" (2005), A.M. Lotmentsev's handbook "History of Southern and Western Slavs" (2013) and of some other works ponder Masaryk's role and efforts during his tenure as President, bringing up different activity aspects of the philosopher, sociologist and outstanding political leader.

The goal of this paper is to reveal the insights into views of the first President of Czecho-Slovakia on the said revolutionary developments in Russia in 1917, and to appraise their significance for the world community.

\section{II. 'RUSSIAN ISSUE' IN T.G. MASARYK'S WORKS OF THE} FIRST THIRD OF THE 20TH CENTURY

The 'Russian issue' had been one of the key topics in Masaryk's political life. In his famous interview with Karel Capek he admits that had read and thought about Russia much, to see what Czechs can and what they should not expect from Russia.

Graduate of the University of Vienna he closely studied classical philosophy, philology and 'practical philosophy' as sociology was called in Austro-Hungary at the time. In 1875, he becomes one of the leaders of young Czech intellectuals in the capital of the Austro-Hungarian Empire.

In 1878, Masaryk publishes the work "Suicide as mass social phenomenon of modern civilization", for which he was named Associate Professor of the University of Vienna. Its core message is that the crisis of contemporary society stands for the crisis of modern man.

This paper mentions Russia for the first time, giving credence to the low suicide rate in the country (according to statistics of that time), which Masaryk attributes to the Orthodox faith.

$\mathrm{He}$ is convinced the phenomenon (suicide) might best be traced via literary works. Masaryk takes the view that the artistic cognition presents the highest form of human cognition. "I say this very sincerely as a man dealing with abstract science. Man attains the most exaltation and... experience in the artistic creation," writes Masaryk in 1844 [1].

This explains his vast reading, including Russian classics. Before writing his book, he had familiarized himself with the novels of Fyodor Dostoyevsky. Pavel N. Milyukov, who knew Masaryk well, is mentioning in his memoires how once he had found in his library a copy of Dostoyevsky's writings covered all over with Masaryk's pencil marks. 
From the researchers' perspective, scientific knowledge and artistic cognition make up mutually complementary methods in the Czech philosopher's epistemology. Therefore, the Russian literature in particular makes the sociological key to understanding Russia [2].

Only in 1996 comes out the Czech translation of Masaryk's "Russia and Europe" (written in late 1890s), presenting his indepth review of the Russian classical writers' art. Masaryk says his keen interest in Russia is due to the fact that many European problems "become clearer to the Europeans themselves through Russian precedents" [3]. In effect, Russia makes "the world on a smaller scale".

Notice that the book's title closely echoes with the work of Nikolai Danilevsky published in 1869 and translated into Czech two years after. In his work, Masaryk is entering into controversy of Danilevsky's Slavophilic ideas.

He writes about Alexander Pushkin, Nikolai Gogol, Ivan Goncharov, speaks with sympathy about Chernyshevsky but is opposed to his ideas of "rational selfishness"; calls Leo Tolstoy the greatest artist; tries to pierce the mystery of Fyodor Dostoyevsky — an intimate expert of human soul — but brushes aside the writer's 'transcendental mysticism', "as an obstruction to an active vital work" [4].

Here he gives an in-depth analysis of the Narodnik movement and Russian Marxism that "had raised up Russian intellectuals", yet denies 'a romanticized revolutionism' and 'the aristocratism of Russian Marxism'.

The process of power shift had been one of the key topics of Masaryk's efforts in the first decades of the $20^{\text {th }}$ century. This explains his keen interest in the processes taking place in the Russian Empire, which he tries to analyze so to determine the right path for his nation.

When the World War I had broken out, the politician stood for the dependence and equal rights of the Slavic nations in the Habsburg monarchy, assuming that these problems may be resolved through reforms. Later he concludes about AustroHungary's unreformability, approaches the radical political wing, comes forward with the program of Middle Europe's reforming, and advocates the Slavonic peoples' independence.

Meantime, he was connecting his vision of the eastern neighbor (Russia) to the hope for restoration of the Czech lands' independence, while cooperation with the grand state might promote stability in Middle Europe. In June 1914, Russian foreign minister Sergei Sazonov was presented the memorandum "The Slavonic Empire Charter", drafted by Karel Kramar (1860-1937), the first prime minister of the Republic (1918-1919), that addressed the issue of the future Czech kingdom's autonomy and its integration into Russia's customs zone. Czechia was meant to become bilingual: Russian language was to become compulsory like Czech [5].

Later in October 1914, Masaryk comes up with ideas of independent strong Czech State, which develops its foreign policy in alliance with Russia. The issue of Royal grandee, according to him, can be decided in favor of the House of Romanovs or in favor of Serbian king Alexander, and the entry into personal union with Great Serbia [6]. These plans were destined to fail, however.

The year 1918 witnessed dissolution of the AustroHungarian Empire and on Europe's map emerged the new state called Czecho-Slovakia, the first President of which became Tomas Garrigue Masaryk.

\section{TOMAS MASARYK ON THE REVOLUTION IN 1917 AND BOLSHEVIKS' EFFORTS}

The October upheaval in Russia in 1917 found T.G. Masaryk in Saint Petersburg, and an almost yearlong stay in Russia helped him sum up the late events and see that revolution lead by 'oligarchical Bolsheviks' was premature and of an anarchistic nature [7]. He saw that Bolsheviks in Russia represented a minority; their leaders had lived abroad great while (and practically became international revolutionists), lost touch with their country and people, unable to grasp the fabric of Western way of life as well. Meantime, the lost war afforded those people an opportunity to return and take power into their hands.

Masaryk gives a very uncomplimentary estimate to the events in October 1917- 'the revolution of individual circles', 'a negative experiment', 'the communism of poverty and devastation' and such.

In the 1920s he publishes a series of articles "Our problems and the Soviet Russia" cautioning Czechs against illusions of the Soviet Russia's experience and against following the example of the established in Russia Marxism.

Masaryk clearly defines the discrepancy between bolshevism and Marxism, acknowledging that K. Marx admitted the possibility of a non-violent revolution. Recalling speeches of Friedrich Engels, whose message to German socialists claimed that an armed revolution is unnecessary because fostered and "mentally competent" socialists would be able to dispose of the old society by means of elections, Masaryk agrees the revolution can be staged otherwise and make an evolutionary democratic revolution.

Marx and Bolsheviks gave different views of the character of revolution-according to Marx, communism stems from antecedencies in the society, evolves inside capitalism and makes the last stage of cultural development, while Lenin saw revolution as a process of curing Russia's existing drawbacks (particularly in education. This is the mistake of Lenin and the mistake of Russian bolshevist revolution, according to Masaryk [8].

Whereas Marx was thinking of a welfare communism, Bolsheviks in reality got 'the equality in poverty and devastation', famine, strangled dissention [9].

The reasons of such state lie in the very nature of Bolshevism. From Masaryk's perspective, illiterate Russians were not ready to face the revolution-semi-knowledge had been "the scourge of Imperial Russia and bolshevist Russia". The bolshevist utopias could well capture the interest of the people, which had endured war and had suffered moral adversities. Retention of power over the 'uneducated masses' required the policy of terror [10]. 
The traditions of Russian revolution go back to the time of Decembrists; this is the revolution of individual circles. Unlike Russians, Czechia has strong parliamentarism traditions; Czech specialists educated the masses, followed the practice of smaller-scale stories thus effectively curtailing the Viennese absolutism.

From this considerations Masaryk draws his weighty conclusion - there must be a non-violent revolution in Czechia, parliamentary, softened up by social reform [11].

A couple of years later the statesman addresses documents of the IX congress of the RCP (March 29 - April 4, 1920), a careful analysis of which let the Czech President make his judgment on Russia's state of affairs, size up and assess the Russian bolshevism as such.

He underlines the economic situation was disastrous in those years. The RCP Congress participants had found solution to the current situation by improving the scientific organization of production and through each man's labor awareness. The Congress enunciated the principle of individualism and adopted decisions on organization of competitions for title of the best professional and on cash rewards to the winners.

However, during three years of the Soviets Russia had turned into single institution with a swelled army of Bolshevik bureaucracy (23 thousand workers out of 100 thousand living in Moscow were public servants), unfree elections, absence of criticism and the flourishing of bribery.

According to Masaryk, the model of industriousness demanded 'an army-like toil' with each deed measured in discipline, efficiency and responsibility. The Soviet Russia, concludes the Czech statesman "has turned into a house built with paper and bonded by blood." [12].

Masaryk's main message on the Russian revolution and Bolsheviks' efforts was that the system established by Lenin was false. That is why Czechs should shed bolshevism and base oneself of the national traditions related to the names of Jan Hus, Jan Amos Komensky and others. Nonetheless, the experience of the revolutionary Russia should be studied, underlined the political leader.

\section{TOMAS MASARYK AND 'RUSSIAN ACTION'}

All thoughts of Tomas Garrigue Masaryk about Russian and the Bolshevik revolution materialized into meaningful action. Following November 1917, tens of thousands of immigrants found themselves in Slavonic countries' metropolises. Prague also became one of the immigrant centers along with Sophia, Belgrade, Bratislava, Paris, etc.

By 1924, the number of refugees from Russia reached almost 30 thousand people. In this period on the initiative of T.G. Masaryk, the government adopts the plan of humanitarian aid to refugees from Russia. The strategy of the "Russian Action", beside the humanitarian aid, outlined specific forms and a scope of measures on providing living conditions for Russian scholars. For this purpose, the Czech government founded in 1921 the Association of district and town representatives ZEMGOR, aimed to implement assistance to different organizations.
Among the institutions functioning in Prague at the time there were Russian People's University, Russian Railway College, Russian Scientific Agricultural Institute, Russian nonclassical secondary school and the Russian Society of Philosophy, established by Russian and Ukrainian philosophers (headed by N.F. Lossky, G.V. Florovsky and others). The Russian Foreign Historical Archive with valuable documents pertaining to the World War I, civil war and revolution was brought to Prague as well. The government funded all institutions. In addition, it is worth mentioning that the funds allocated by the Czech Socialist Republic, supported 65 Russian schools located in West European countries (Finland, Estonia, Poland, Greece, Bulgaria and other).

\section{CONCLUSION}

Reflections on the developments encountered by Russia in the early $20^{\text {th }}$ century reinforced the Czech president in the opinion that on the threshold of history, first and foremost, the choice of the nation's path must be governed by national traditions-for Czechs this is the continuation of traditions of Jan Gus, J.A. Komensky, F. Palatcky, K. Havlicek-Borovsky and other 'awakeners'.

"To avoid tragic headwinds during the regime change; the 'revolutionary terrorism' that dominated the Russian revolution does not suit Czechs: the nature of our revolution is peaceful, parliamentary; "we cannot afford Moscow splendor," concludes Tomas Masaryk.

It seems impossible to cover all of many-sided efforts of the Czech Republic's first President and his contemplations about Russia in one brief article. In conclusion, I would like to offer some poetic lines from the memoirs of E.D. Kuskova about Masaryk, highlighting his essential vision of Russia: "rejoicing over the victory of the Czech people, we, Russian intellectuals, keep repeating the words that had encouraged Masaryk before the battle for freedom "I do believe, great God, that the vortex of Thy wrath will flash past, and the right and might will return to you, oh, Russian nation." With these words closely echo the wonderful lines written by Nikolai Gumilev, congruent with Masaryk's prayer: "Don't believe in Russia burnt to ashes by unimaginable woe: / It is wild waves over the sea, / But its deep is in repose" [13].

\section{REFERENCES}

[1] M. Petrusek, N.P. Narbut, Prolusion // TG Masaryk: PhilosophySociology-Policy. Selectas, M.: RUDN Press, 2003, p.11.

[2] Ibid, p.17

[3] Masaryk T.G. Rusko a Evropa. Sv. II. Spisy T.G.Masarika, Sv.Praha, 1996, p. 430.

[4] Czechia and Slovakia in the XX century: Historical essays: in two books / Executive editor V.V. Marjina, Institute of Slavonic Studies, M.: Nauka, Book 1, 2005, p. 453.

[5] Ibid, p. 50.

[6] Ibid, p. 53.

[7] T.G. Masaryk, "Soviet Russia and we", TG Masaryk: PhilosophySociology-Politics. Selectas. M.: RUDN Press, 2003, p. 489.

[8] Ibid, p. 509.

[9] Ibid, p. 493.

[10] Ibid, p. 197. 
[11] Ibid, p. 527.

[12] Ibid, p. 503.

[13] E.D. Kuskova, "Tomas Garrigue Masaryk and Russian intelligentsia" // T.G. Masaryk and 'Russian Action' of the Czech government: On 150 years of the birth of T.G. Masaryk, Proceedings of the International scientific conference, M.: Russky Put', 2005, p. 210. 